\title{
Genomic and metagenomic analysis of microbes in a soil environment affected by the 2011 Great East Japan Earthquake tsunami
}

\author{
Satoshi Hiraoka ${ }^{1 *}$, Asako Machiyama $^{2}$, Minoru ljichi ${ }^{3}$, Kentaro Inoue $^{3}$, Kenshiro Oshima $^{4}$, \\ Masahira Hattori ${ }^{4}$, Susumu Yoshizawa ${ }^{3}$, Kazuhiro Kogure ${ }^{3}$ and Wataru Iwasaki ${ }^{1,2,3 *}$
}

\begin{abstract}
Background: The Great East Japan Earthquake of 2011 triggered large tsunami waves, which flooded broad areas of land along the Pacific coast of eastern Japan and changed the soil environment drastically. However, the microbial characteristics of tsunami-affected soil at the genomic level remain largely unknown. In this study, we isolated microbes from a soil sample using general low-nutrient and seawater-based media to investigate microbial characteristics in tsunami-affected soil.

Results: As expected, a greater proportion of strains isolated from the tsunami-affected soil than the unaffected soil grew in the seawater-based medium. Cultivable strains in both the general low-nutrient and seawater-based media were distributed in the genus Arthrobacter. Most importantly, whole-genome sequencing of four of the isolated Arthrobacter strains revealed independent losses of siderophore-synthesis genes from their genomes. Siderophores are low-molecular-weight, iron-chelating compounds that are secreted for iron uptake; thus, the loss of siderophore-synthesis genes indicates that these strains have adapted to environments with high-iron concentrations. Indeed, chemical analysis confirmed the investigated soil samples to be rich in iron, and culture experiments confirmed weak cultivability of some of these strains in iron-limited media. Furthermore, metagenomic analyses demonstrated over-representation of denitrification-related genes in the tsunami-affected soil sample, as well as the presence of pathogenic and marine-living genera and genes related to salt-tolerance.
\end{abstract}

Conclusions: Collectively, the present results would provide an example of microbial characteristics of soil disturbed by the tsunami, which may give an insight into microbial adaptation to drastic environmental changes. Further analyses on microbial ecology after a tsunami are envisioned to develop a deeper understanding of the recovery processes of terrestrial microbial ecosystems.

Keywords: Arthrobacter, Comparative genomics, Environmental microbes, Metagenomics, Siderophore, Tsunami

\section{Background}

On March 11, 2011, the Great East Japan Earthquake occurred off the coast of Tohoku, Japan. The earthquake triggered large tsunami waves, which flooded broad areas of land along the Pacific coast and changed the soil environment due to seawater and sludge that originated from

\footnotetext{
*Correspondence: hiraoka@cb.k.u-tokyo.ac.jp; iwasaki@bs.s.u-tokyo.ac.jp 1 Department of Computational Biology and Medical Sciences, Graduate School of Frontier Sciences, the University of Tokyo, 277-8568, Chiba, Japan

2 Department of Biological Sciences, Graduate School of Science, the University of Tokyo, 113-0032, Tokyo, Japan

Full list of author information is available at the end of the article
}

marine sediments [1]. Previous studies showed that following the Indian Ocean tsunami of December 26, 2004, the tsunami-affected areas maintained high-salinity conditions for over eight months [2], and there were also changes in several chemical characteristics, including an increase in organic matter content [3], increase in nitrate and phosphate content [4], increase in heavy-metal ion concentrations [5-7], decrease in $\mathrm{pH}$, and increase in electrical conductivity [8]. Increases in salinity and organic matter were also reported at a number of places along the pacific coast following the Tohoku tsunami [1]. 
Such changes in the soil environment after the tsunami are also likely to have an impact on the ecosystem. There have been many studies conducted to date investigating how such changes affect plants; for example, vegetation senescence was reported after the Indian Ocean tsunami $[7,9,10]$ and flora variations on sandy beaches were observed after the Tohoku tsunami [11]. On the other hand, only a few studies have evaluated the effects of a tsunami on microbes. Somboonna et al. applied 16S ribosomal RNA (rRNA) amplicon sequencing to the soil affected by the Indian Ocean tsunami and observed changes in the microbial population structure [12]. Wada et al. also used 16S rRNA amplicon sequencing to analyze samples of the sludge brought ashore by the Tohoku tsunami and identified several pathogenic and sulfatereducing bacterial groups [13]. However, no study has yet investigated the microbial characteristics of tsunamiaffected soil at the genomic level.

In this study, we evaluated the microbial characteristics of a soil environment affected by the Tohoku tsunami, using whole-genome and shotgun metagenome sequencing approaches. Notably, whole-genome sequencing of four Arthrobacter strains isolated from the tsunami-affected soil sample revealed that siderophoresynthesis genes were independently lost in each genome. Siderophores are compounds that function in iron absorption [14-16], and these gene losses were consistent with the results of soil chemical analysis and culture experiments under iron-controlled conditions. Furthermore, metagenomic analyses indicated over-representation of denitrification-related genes in the tsunami-affected soil sample, as well as the existence of pathogenic and marineliving genera and genes related to salt-tolerance.

\section{Materials and methods \\ Sample collection}

Soil samplings were conducted at Hiyoriyama $\left(38^{\circ} 15^{\prime} 20^{\prime \prime} \mathrm{N}, 141^{\circ} 0^{\prime} 42^{\prime \prime} \mathrm{E}\right)$ and Amamiya $\left(38^{\circ} 16^{\prime} 35^{\prime \prime} \mathrm{N}\right.$, $140^{\circ} 52^{\prime} 16^{\prime \prime E}$ ) in Sendai city, Miyagi, Japan, in July 2012 (Fig. 1). If needed, the owners of the lands gave permission to conduct the study on these sites. We confirm that the study did not involve endangered or protected species. The Hiyoriyama site is $0.5 \mathrm{~km}$ off the coastline and was affected by the tsunami, whereas the Amamiya site is $12 \mathrm{~km}$ off the coastline and was not affected; the two sites are $13 \mathrm{~km}$ apart. The surface soil was removed to a $5 \mathrm{~cm}$ depth before sampling. Intermingled plants were carefully removed using tweezers, and soil that passed through a $2.0-\mathrm{mm}$ pore-sized sieve was collected. The collected soil samples were transported to the laboratory at $4{ }^{\circ} \mathrm{C}$ and immediately stored at $-80{ }^{\circ} \mathrm{C}$ until the subsequent analysis.

Seawater sampling was conducted at St. $5\left(38^{\circ} 06^{\prime} 00^{\prime \prime} \mathrm{N}\right.$, $\left.142^{\circ} 15^{\prime} 00^{\prime \prime} \mathrm{E}\right)$ and St.6 $\left(38^{\circ} 22^{\prime} 59^{\prime \prime} \mathrm{N}, 142^{\circ} 43^{\prime} 01^{\prime \prime} \mathrm{E}\right)$ off the coast of Miyagi, Japan in the Pacific Ocean, in August 2012, during the KT-12-21 cruise of R/V Tansei-Maru (JURCAOS, JAMSTEC). The St.5 and St.6 stations are located $110 \mathrm{~km}$ and $150 \mathrm{~km}$ from Sendai city, respectively. Surface seawater was collected in a prewashed bucket and immediately spread onto agar plates on a research vessel.

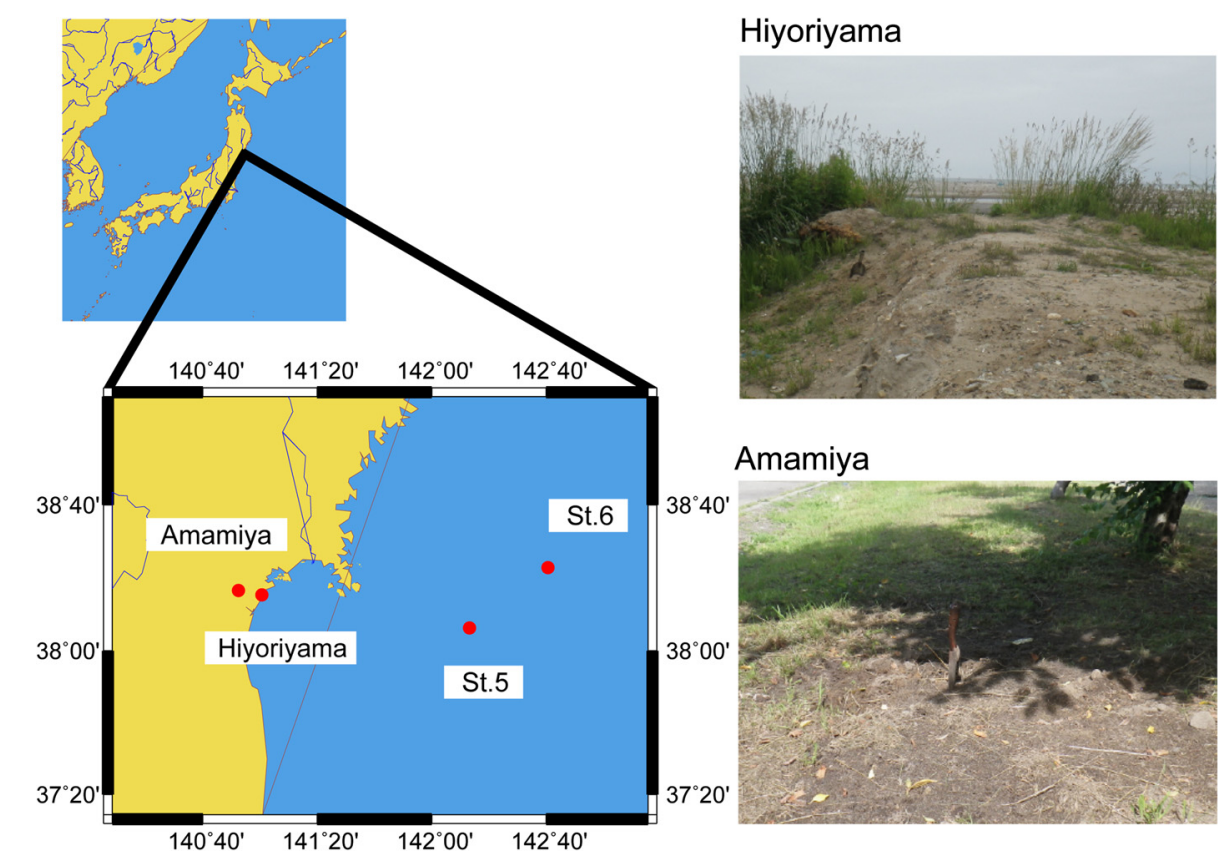

Fig. 1 A map and photos of the sampling sites in a coastal area of Sendai, Japan. The Tohoku tsunami reached Hiyoriyama, but not Amamiya 


\section{Isolation and 16S rRNA sequencing}

R2A medium (Wako Pure Chemical Industries) was used to cultivate microbial strains that grow under general, low-nutrient condition, and ZoBell marine medium (Becton Dickinson and Company) was used to cultivate microbial strains that have adapted to a seawater-affected condition. Soil samples were thawed at $4{ }^{\circ} \mathrm{C}$ overnight, suspended in R2A or ZoBell liquid medium, and plated to the corresponding agar medium at a density of $10^{-4} \mathrm{~g}$ soil per plate with five replicates. The plates were incubated at $20{ }^{\circ} \mathrm{C}$ for 7 days before colony counting and picking. To obtain strains that could grow in both media, single colonies on the R2A agar plates were transferred to ZoBell agar plates with sterilized sticks, incubated at $20^{\circ} \mathrm{C}$ for 7 days, and isolated by spread-plating on ZoBell agar at $20{ }^{\circ} \mathrm{C}$. The seawater samples were plated to R2A and ZoBell agar at a volume of $100 \mu \mathrm{L}$ seawater per plate with three replicates. The plates were incubated at $20^{\circ} \mathrm{C}$ for 7 days before colony counting and picking.

To sequence 16S rRNA genes, seven strains that were isolated from the Hiyoriyama site and could actively grow in both R2A and ZoBell media were randomly selected. After incubation in ZoBell liquid medium, DNA was extracted using Wizard Genomic DNA Purification Kit (Promega). The 16S rRNA genes were amplified using a standard polymerase chain reaction protocol with the primers 27F (5'-AGAGTTTGATCMTGGCTCAG-3') and 1492R (5'-GGCTACCTTGTTACGACTT-3') [17], and sequenced by the Sanger method.

\section{Whole-genome sequencing and analysis}

Four strains of the Arthrobacter genus that were isolated from the Hiyoriyama site and were cultivable in both R2A and ZoBell media were targeted for wholegenome sequencing. Genomic DNA was extracted by the phenol-chloroform method. Two strains (named Hiyo4 and Hiyo8) were sequenced using PacBio RS II (Pacific Biosciences) according to the manufacturer protocols. De novo genome assembly of the 62,608 (Hiyo4) and 65,240 (Hiyo8) raw reads obtained from the Sprai pipeline (http://zombie.cb.k.u-tokyo.ac.jp/sprai/) successfully generated one and three circular contigs, respectively, after manual curation. The other two strains (Hiyol and Hiyo6) were sequenced using GS FLX+ System (Roche) and Ion PGM (Thermo Fisher Scientific) according to the manufacturer protocols. De novo genome assembly of the 301,881 (Hiyo1) and 267,295 (Hiyo6) reads obtained from the Newbler assembler [18] generated 38 and 630 scaffolds, respectively.

Coding sequences (CDSs) were predicted by applying Prodigal [19] to the contig sequences. Functional annotation was performed by blastp searches [20] against the Swiss-Prot [21] and eggNOG v4.0 [22] databases with a cut-off e-value $\leq 1 \mathrm{E}-5$. Transfer RNA (tRNA) and rRNA sequences were predicted using tRNAscan-SE [23] and RNAmmer [24], respectively, with default settings.

For comparative genome analysis, all 21 publicly available genome sequences (6 complete and $15 \mathrm{draft}$ sequences) of the Arthrobacter genus were downloaded from GenBank [25] via EzGenome (http://www. ezbiocloud.net/ezgenome) in January 2015 (Additional file 1). The CDSs of the four isolated and 21 downloaded genomes were subjected to blastp searches against the eggNOG database [22] with cut-off e-value $\leq 1 \mathrm{E}-5$ and identity $\geq 90 \%$.

For construction of a phylogenetic tree, the 16S rRNA sequences of 56 Arthrobacter type strains and Streptomyces coelicoflavus NBRC $15399^{\mathrm{T}}$ were additionally downloaded from the RDP webserver [26]. Streptomyces coelicoflavus NBRC $15399^{\mathrm{T}}$ was used as an outgroup [27]. The 16S rRNA sequences of the total 82 strains were subjected to multiple alignment using MUSCLE [28] with default settings. A maximum-likelihood (ML) tree was generated by MEGA 6 [29] with the K80 substitution model with a gamma distribution and invariant sites $(\mathrm{K} 2+\mathrm{G}+\mathrm{I})$, which was the AIC-selected model, and 1000 bootstrap replicates. An ML tree of the total 17 genomeavailable strains was constructed on the basis of the set of 400 conserved bacterial marker genes using PhyloPhlAn [30] and MEGA 6 [29] with the WAG substitution model that incorporates gamma distribution and the amino-acid frequencies of the dataset (WAG+G+F), which was the AIC-selected model, and 1000 bootstrap replicates.

\section{Culture assays of iron dependency}

To determine the difference in iron tolerance among strains in relation to the genetic analysis results, culture assays were conducted at different iron concentrations. In addition to the four isolated Arthrobacter strains, we cultivated four closely related and genome-sequenced species, A. aurescens Phillips $1953^{\mathrm{T}}$ (JCM $\left.1330^{\mathrm{T}}\right), A$. chlorophenolicus $\mathrm{A}^{\mathrm{T}}$ (JCM $12360^{\mathrm{T}}$ ), A. globiformis Conn $1928^{\mathrm{T}}\left(\mathrm{JCM} 1332^{\mathrm{T}}\right.$ ), and A. phenanthrenivorans Sphe $3^{\mathrm{T}}$ $\left(\mathrm{JCM} 16027^{\mathrm{T}}\right.$ ). All four species had intact siderophoresynthesis genes in their genomes. These strains were provided by the Japan Collection of Microorganisms, BioResource Center, RIKEN and National BioResource Project of Ministry of Education, Culture, Sports, Science and Technology, Japan.

Iron-controlled, modified MM9 medium was prepared as follows. A solution containing $0.3 \mathrm{~g} / \mathrm{L} \mathrm{KH_{2 }} \mathrm{PO}_{4}, 0.5 \mathrm{~g} / \mathrm{L}$ $\mathrm{NaCl}, 1.0 \mathrm{~g} / \mathrm{L} \mathrm{NH}{ }_{4} \mathrm{Cl}, 6.0 \mathrm{~g} / \mathrm{L} \mathrm{NaOH}$, and $30.24 \mathrm{~g} / \mathrm{L}$ PIPES was adjusted to $\mathrm{pH} 7.0$ with $\mathrm{NaOH}$. After autoclaving, separately sterilized solutions of $10 \mathrm{~mL}$ of $20 \mathrm{wt} \%$ glucose, 1 $\mathrm{mL}$ of $1 \mathrm{M} \mathrm{MgCl}_{2}$, and $0.1 \mathrm{~mL}$ of $1 \mathrm{M} \mathrm{CaCl}_{2}$ were added to $1 \mathrm{~L}$ of the solution [31]. Then, the iron concentration was adjusted to $0,0.1,1$, or $10 \mu \mathrm{M}$ with a $\mathrm{FeCl}_{3}$-containing solution that was prepared in the same manner. 
Each strain was precultured until its optical density at $660 \mathrm{~nm}\left(\mathrm{OD}_{660}\right)$ reached 0.1 in the iron-free modified MM9 liquid medium. Then, $100 \mu \mathrm{L}$ of the suspension was inoculated to $50-\mathrm{mL}$ tubes containing $10 \mathrm{~mL}$ of the iron-controlled, modified MM9 medium. Among the additional four strains, only $A$. phenanthrenivorans Sphe3 showed growth in the modified MM9 medium. The tubes were incubated at $30^{\circ} \mathrm{C}$ on a linear shaker at $200 \mathrm{rpm}$ for 3 days, and the $\mathrm{OD}_{660}$ was measured periodically during the incubation period. The growth curve was fitted to the logistic model to calculate the maximum growth rate.

\section{Soil chemical analysis}

The soil samples were subjected to chemical analysis for $\mathrm{pH}$, electrical conductivity, and concentrations of total organic carbon, total nitrogen, nitrate, nitrite, ammonium, effective phosphate, exchangeable ions $\left(\mathrm{K}^{+}, \mathrm{Ca}^{2+}, \mathrm{Mg}^{2+}\right.$, $\mathrm{Na}^{+}$, and $\left.\mathrm{Mn}^{2+}\right)$, available iron (Fe), chloride ion $\left(\mathrm{Cl}^{-}\right)$, sulfate ion $\left(\mathrm{SO}_{4}^{2-}\right)$, eluted heavy metals $(\mathrm{Cd}, \mathrm{Cr}(\mathrm{VI})$, total $\mathrm{Hg}$, alkyl mercury, $\mathrm{Pb}, \mathrm{As}$, and $\mathrm{B})$, and contained heavy metals (Cd, Cr (VI), Hg, Pb, As, B, Cu, Zn, and $\mathrm{Ni}$ ). The analysis was conducted by Createrra Inc. (Tokyo, Japan).

\section{Shotgun metagenome sequencing and analysis}

Metagenomic DNA was extracted using PowerSoil DNA Isolation Kit (MoBio Laboratories). Shotgun metagenome sequencing was performed using the GS FLX+ System according to the supplier's protocol. Duplicated reads were removed by CD-HIT-454 [32].

Taxonomic assignment was performed using Kraken [33] against complete prokaryotic genomes from RefSeq [34]. CDS prediction was performed using MetaProdigal [35]. CDSs less than 30 amino acids in length were excluded from further analysis. Functional annotations were based on blastp searches against the eggNOG [22] and Swiss-Prot [21] databases with a cut-off e-value $\leq 1 \mathrm{E}-5$.
SortMeRNA [36] was applied to the shotgun metagenome data to extract $16 \mathrm{~S}$ rRNA sequences. For each extracted 16S rRNA sequence, a blastn search was performed against MetaMetaDB [37] and the top hit sequences with e-value $\leq 1 \mathrm{E}-10$ and identity $\geq 90 \%$ were retrieved. Microbial habitability index (MHI) scores were calculated as described previously [37].

\section{Data deposition}

The whole-genome and plasmid sequence data of Hiyo1, Hiyo4, Hiyo6, and Hiyo8 were deposited in the DDBJ/ENA/GenBank database under the BioSample ID SAMD00024042, SAMD00024043, SAMD00024044, and SAMD00024045, respectively. The shotgun metagenome sequence data of Hiyoriyama and Amamiya were deposited in the DDBJ/ENA/GenBank database under BioSample ID SAMD00023516 and SAMD00023517, respectively. All data were registered under BioProject ID PRJDB3373.

\section{Results and discussion}

Isolation of microbial strains

To investigate whether the microbial community at the Hiyoriyama (tsunami-affected) site contained more microbes that are adapted to seawater-affected conditions than that at the Amamiya (tsunami-unaffected) site, we conducted culture experiments using R2A (general low-nutrient) and ZoBell (seawater-based) media. At Hiyoriyama, the mean ( \pm standard deviation) numbers of colony forming unit (CFU) per gram of soil were 7.0 \pm 3.9 $\times 10^{5}$ and $3.0 \pm 2.0 \times 10^{5}$ on R2A and ZoBell, respectively. At Amamiya, these numbers of CFU were $21.8 \pm 4.7 \times 10^{5}$ and $3.6 \pm 2.3 \times 10^{5}$. The ZoBell/R2A CFU ratios were 0.43 and 0.17 at Hiyoriyama and Amamiya, respectively, indicating that the Hiyoriyama site would be comparatively enriched with microbes adapted to a seawater-affected condition at 10 months after the tsunami. For comparison,

Table 1 Whole-genome sequencing of the isolated Arthrobacter sp. strains

\begin{tabular}{|c|c|c|c|c|}
\hline & Hiyo1 & Hiyo6 & Hiyo4 & Hiyo8 \\
\hline Sequencing platform & GS FLX+ \& lon PGM & GS FLX+\& Ion PGM & PacBio RS II & PacBio RS II \\
\hline Scaffolds & 38 & 630 & 1 & 3 \\
\hline Contigs & 1,685 & 2,450 & 1 & 3 \\
\hline Total genome size (bp) & $5,543,883^{a}$ & $2,594,729^{a}$ & $3,779,248$ & $4,698,617^{a}$ \\
\hline N50 (bp) & 4,950 & 2,656 & - & - \\
\hline Coverage & $20 x$ & $24 x$ & $79 x$ & $42 x$ \\
\hline GC content (\%) & 63.2 & 63.3 & 65.0 & 63.8 \\
\hline CDSs & 5,292 & 3,767 & 5,120 & 7,041 \\
\hline rRNAs & 2 & 3 & 12 & 15 \\
\hline tRNAs & 51 & 33 & 50 & 53 \\
\hline
\end{tabular}

a Plasmid sequences were not excluded 
surface seawater samples collected at St. 5 and St. 6 in the offshore were spread onto both agar plates. The numbers of CFU per milliliter of seawater were $12.7 \pm 13.3 \times 10^{1}$ and $81.7 \pm 43.6 \times 10^{1}$ on R2A and ZoBell, respectively. As expected, the ZoBell/R2A CFU ratio (6.4) was significantly higher at the offshore sites than at Amamiya and Hiyoriyama ( $\mathrm{p}$-value $<0.05$, $\mathrm{t}$-test).
To isolate microbial strains that are potentially adapted to both types of environments from Hiyoriyama, we aseptically transferred the microbial colonies grown on R2A to ZoBell agar plates. Seven isolated colonies were randomly picked up and their $16 \mathrm{~S}$ rRNA genes were sequenced. Unexpectedly, all of the strains were found to belong to a single genus, Arthrobacter. The genus

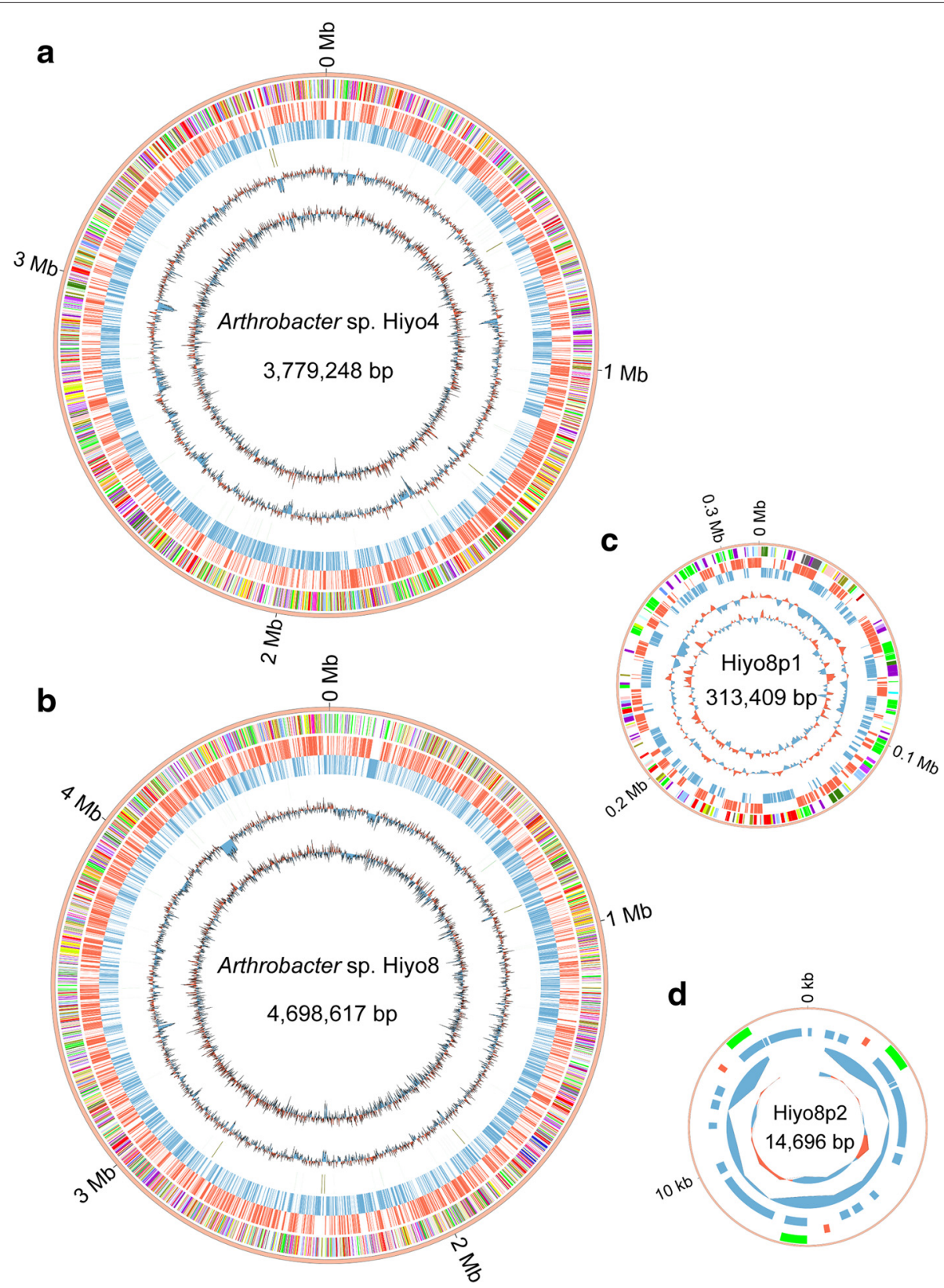

Fig. 2 Circular diagrams of the chromosomes and plasmids of Arthrobacter sp. Hiyo4 and Hiyo8. Each concentric circle represents genomic data of Arthrobacter sp. a Hiyo4 and b Hiyo 8 chromosomes and the Hiyo $8 \mathbf{c p} 1$ and $\mathbf{d}$ p2 plasmids. The outermost circle is the contig, the 2nd circle are the coding genes colored according to the functional categories of the eggNOG database (see additional file 2 for color coding), the $3 \mathrm{rd}$ and 4 th circles are the coding genes on the leading (red) and lagging (blue) strands, respectively, the 5th circle are the rRNA (brown) and tRNA (green) genes, the 6 th circle is the GC content (1-kb sliding window), and the innermost circle represents the GC skew (1-kb sliding window) 
Arthrobacter is an aerobic, gram-positive member of the family Micrococcaceae, Actinobacteria [38, 39]. This genus is broadly found in soils, as well as in extreme environments, including the deep subsurface [40], arctic ice [41], radioactive sites [42], and heavy metal-contaminated sites [43]. Some Arthrobacter species were reported to tolerate drastic environmental stresses, e.g., desiccation [44], starvation [45], heavy metals [46, 47], and radioactivity [48]. Furthermore, at the time of analysis, 6 complete and 15 draft genome sequences were available for comparative genome analysis. Because of these characteristics, the isolated Arthrobacter strains were targeted as a possible platform for exploring genomic features that may be related to microbial adaptation to drastically changed environments.

\section{Whole-genome sequencing of the isolated Arthrobacter strains}

The whole-genome sequences of four Arthrobacter sp. strains were determined (Table 1). Assembly using the reads from PacBio RS II showed the complete genomes of two strains: Hiyo4 with one circular chromosome (3.8 Mbp), and Hiyo8 with one circular chromosome (4.7 Mbp) and two plasmids (0.3 Mbp and $15 \mathrm{kbp}$ ) (Fig. 2). Assembly using reads from GS FLX+ and Ion PGM System produced 38 and 630 scaffolds for two strains, Hiyo1 and Hiyo6, respectively.
The total genome sizes of the four strains ranged from 2.6 to $5.5 \mathrm{Mbp}$. Although the genome sizes of Hiyo4 and Hiyo8 were within the range of the previously reported genomes (Additional file 1), their CDS numbers were exceptionally large, possibly because of additional genes that facilitate adaptation to different environmental conditions. The functional categories of eggNOG were assigned to $61-66 \%$ of the CDSs, and the GC content was $63-65 \%$, which is similar to that of the previously reported genomes (59-67\%) (Additional file 1).

\section{Phylogenetic analysis and comparative genomics}

To reveal the phylogenetic relationships among the four strains Hiyo1, Hiyo4, Hiyo6, and Hiyo8, we constructed a maximum-likelihood phylogenetic tree of the Arthrobacter genus based on 16S rRNA gene sequences (Additional file 3 ). The tree reliably placed the four isolated strains within this genus. There was only one nucleotide base gap between the 16S rRNA sequences of Hiyo1 and Hiyo8, suggesting their close relationship. Hiyo4 and Hiyo6 were classified into different clades in the tree.

Subsequently, we conducted comparative genome analysis with 21 publicly available Arthrobacter genomes. The relative abundance of the CDSs assigned to each eggNOG functional category in each genome (Additional file 2) shows small difference among these Arthrobacter strains, i.e., their genomes have similar functional

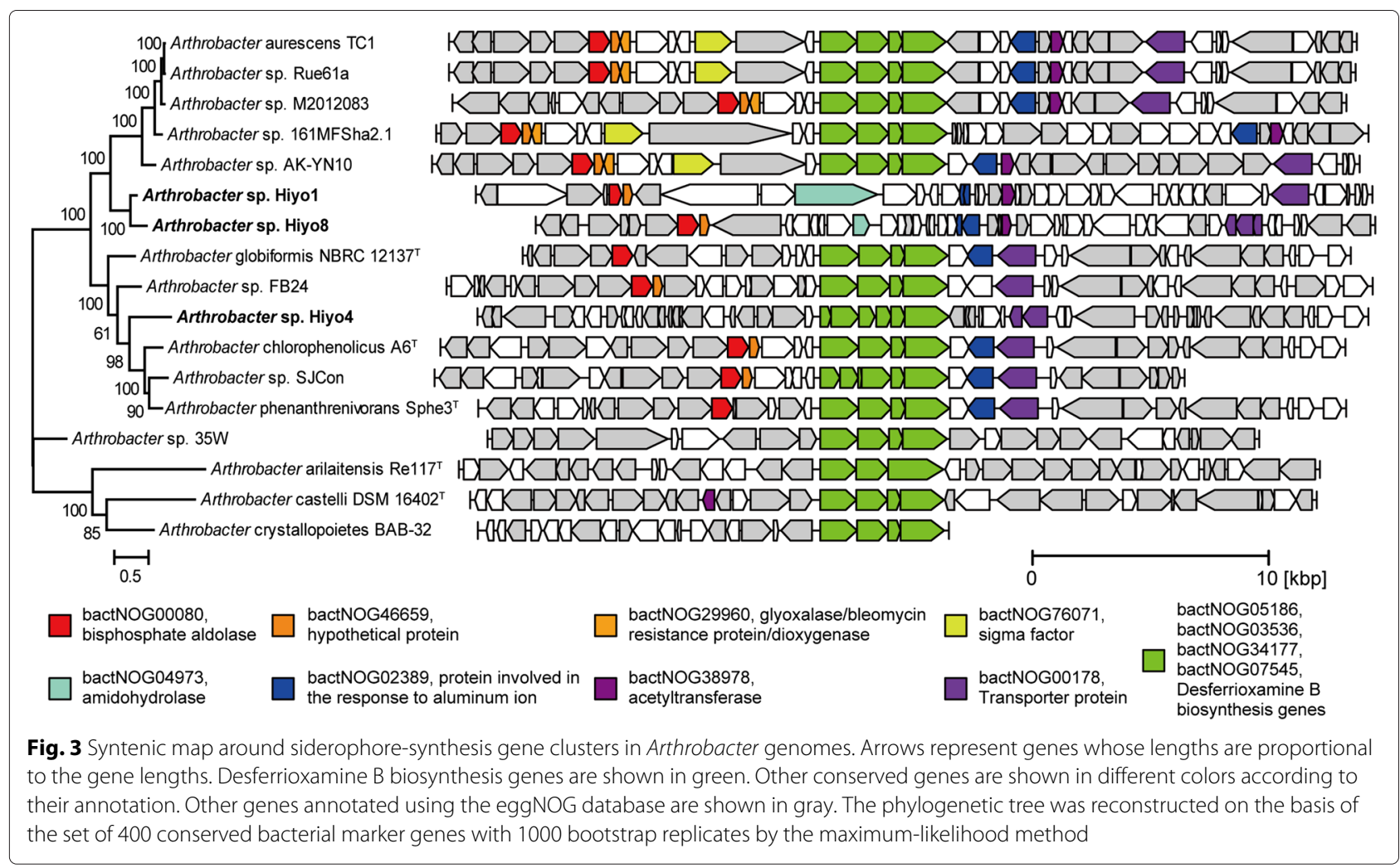


composition overall. The most striking difference between the Arthrobacter genomes isolated from the tsunamiaffected soil and those isolated from other environments was that desferrioxamine B biosynthesis genes were independently lost in each of the former genomes. Within 14 publicly available, high-quality Arthrobacter genomes, the desferrioxamine B biosynthesis gene cluster and surrounding synteny structures were found to be highly conserved (Fig. 3). On the other hand, the desferrioxamine $\mathrm{B}$ biosynthesis gene cluster was entirely absent in the completed Hiyo1 and Hiyo8 genomes: the desA (pyridoxal-dependent decarboxylase) and $\operatorname{des} B$ (L-lysine 6-monooxygenase) genes of the cluster had nonsense mutations in the Hiyo4 genome, and neither the cluster nor the surrounding synteny structure was found in the Hiyo6 genome.

Desferrioxamine B is a member of the siderophores family of molecules, which are low-molecular-weight, iron-chelating compounds secreted by many microbes and plants for the uptake of iron [14-16, 49, 50]. The ability to use siderophores confers an ecological advantage when iron is limited [51]. Many Arthrobacter strains have a desferrioxamine $B$ biosynthesis gene cluster, which is composed of four genes, named $\operatorname{des} A B C D$, for siderophore production $[52,53]$. It should be noted that no iron-rich media were used during the isolation procedures.

The independent losses of the siderophore-synthesis genes are not likely to have occurred by chance but likely because of natural selection. Thus, these Arthrobacter strains were assumed to have been under weak selection pressure for iron uptake and to be at a growth disadvantage under low iron concentrations. To evaluate the growth potentials of these strains under various iron concentrations, culture experiments in iron-controlled media were conducted (Fig. 4; Additional file 4). Two of the isolated strains (Hiyol and Hiyo8) required 10 $\mu \mathrm{M} \mathrm{Fe}^{3+}$ iron for rapid growth, whereas a control strain (A. phenanthrenivorans Sphe3) that has a desferrioxamine $\mathrm{B}$ biosynthesis gene cluster required $1 \mu \mathrm{M} \mathrm{Fe}^{3+}$ iron (Fig. 4). Notably, under the $1 \mu \mathrm{M} \mathrm{Fe}^{3+}$ iron concentrations, the maximum growth rates of Hiyo1 and Hiyo8 (1.08 \pm $0.14 \times 10^{-2}$ and $1.15 \pm 0.32 \times 10^{-2}$, respectively) was significantly smaller than that of Sphe3 $\left(2.34 \pm 0.20 \times 10^{-2}\right)$ (p-value $<0.05$, t-test with Bonferroni correction). Hiyo4 and Hiyo6 showed very weak growth even with $10 \mu \mathrm{M}$
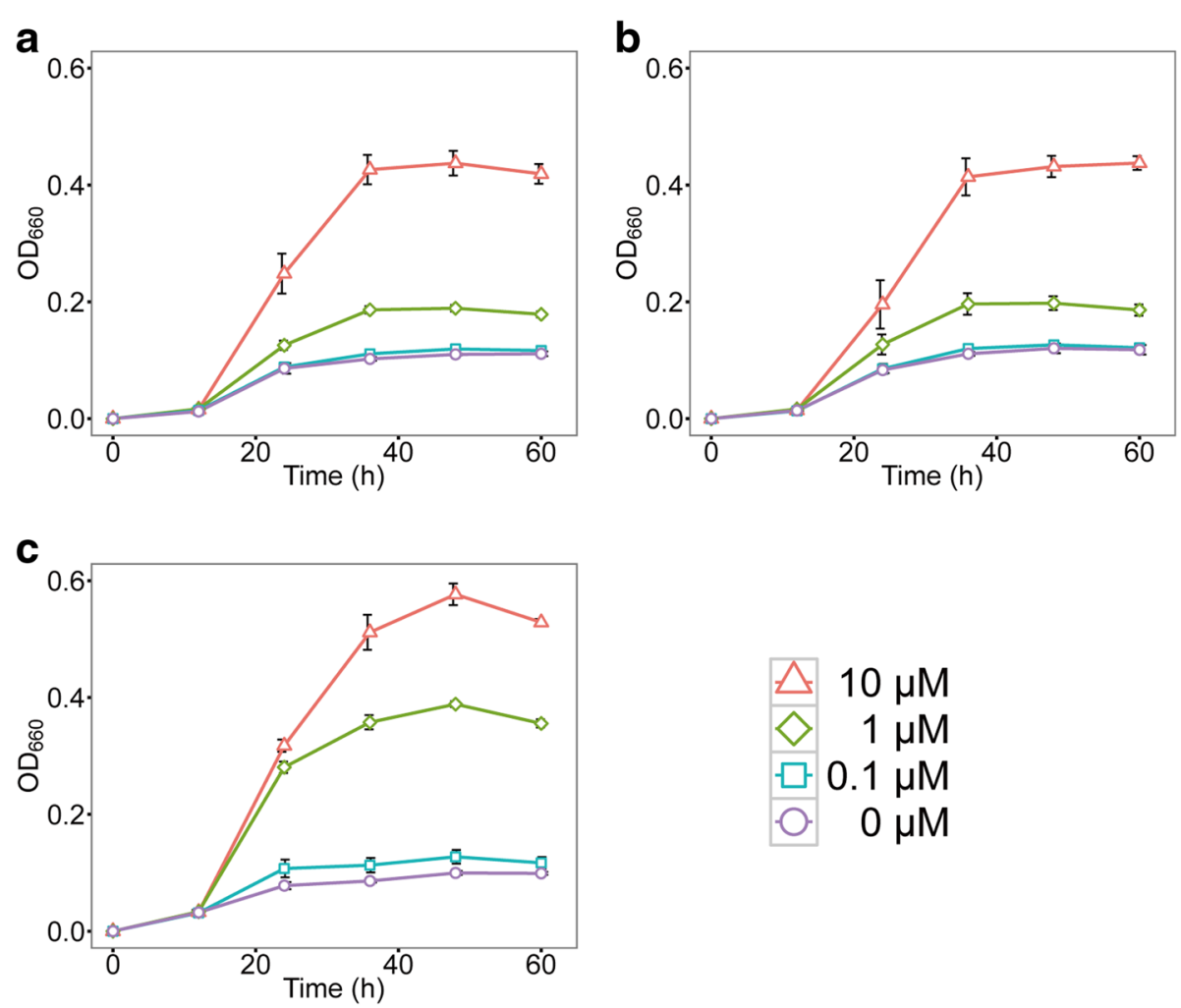

Fig. 4 Growth curves of the Arthrobacter strains at different iron concentrations. Growth was measured as optical density values at $660 \mathrm{~nm}$ in modified MM9 medium containing different concentrations of iron (III): 0.0, 0.1, 1, and $10 \mu \mathrm{M}$. Growth curves of Arthrobacter sp. Hiyo1 (a), Arthrobacter sp. Hiyo8 (b), and A. phenanthrenivorans Sphe3 (c) are shown. Growth curves of Hiyo4 and Hiyo6, which showed very weak growth in the modified MM9 medium, are displayed in Additional file 4 
$\mathrm{Fe}^{3+}$ iron, possibly because these two strains require additional nutrients for growth (Additional file $4 \mathrm{C}$ and D).

Based on these results, we hypothesized that strains with de novo mutations in siderophore synthesis genes or those that originally lacked these genes would be selected under iron-enriched conditions. Notably, siderophore production by soil-living microbes has been reported to help various plants absorb iron (e.g., tomato, cucumber, barley, and corn) [54-56] and has been associated with $\mathrm{N}_{2}$ fixation (pigeon pea) [57]; therefore, these observed genomic changes in the bacterial communities might also relate to plant growth.

\section{Soil chemical analysis}

To confirm that the tsunami-affected soil sample analyzed in this study did in fact have a high iron concentration and/or chemical characteristics that similar to those reported in previous studies on tsunami-affected soils, chemical analysis of the soil samples of the Hiyoriyama and Amamiya sites was conducted (Table 2). As expected, Hiyoriyama contained 13 times more iron than Amamiya, which is consistent with the observed losses of the siderophore-synthesis genes. Because Hiyoriyama was also found to be substantially rich in sulfate (e.g., $\mathrm{SO}_{4}^{2-}$ levels were 169 times higher in Hiyoriyama than Amamiya), the iron was possibly provided in the form of iron-sulfur compounds (i.e., $\mathrm{FeS}, \mathrm{FeS}_{2}, \mathrm{Fe}_{2} \mathrm{~S}_{3}$ ), which are contained in seawater and sediment [58]. These sulfurs can be oxidized into sulfates via biological processes in the presence of electron acceptors [59], including nitrate $\left(\mathrm{NO}_{3}^{-}\right)$[60-63]. We propose that the substantially smaller amount of nitrate in Hiyoriyama than Amamiya ( $>13$ fold) may reflect this process.

Except for these chemicals, the characteristics of the two samples were similar overall, suggesting that the two soil samples share a similar geological origin. In particular, the absence of heavy metals such as $\mathrm{Pb}, \mathrm{Hg}$, and $\mathrm{Cu}$ in Hiyoriyama might indicate that the soil was not completely covered or replaced with marine sediments. In addition, the similarities in electrical conductivity and $\mathrm{Na}^{+}$and $\mathrm{Cl}^{-}$content between samples can be attributed to the effects of rain; in the case of the 2004 Indian Ocean tsunami, water-soluble salts derived from the tsunami were strongly reduced after a rainy season in a coastal area in Thailand [64].

\section{Shotgun metagenome sequencing}

To investigate differences in the taxonomic compositions and protein-coding gene abundance between the two samples, shotgun metagenome sequencing was conducted (Table 3). After quality control, 822,865 and 961,221 reads were obtained from the Hiyoriyama and Amamiya samples, respectively.
Table 2 Chemical characteristics of the soil samples

\begin{tabular}{|c|c|c|c|}
\hline & & Hiyoriyama & Amamiya \\
\hline $\mathrm{pH}$ & - & 5.9 & 6.1 \\
\hline Electrical conductivity & $\mathrm{dS} / \mathrm{m}$ & 0.23 & 0.02 \\
\hline Total organic carbon & $\mathrm{g} / \mathrm{kg}$ & 3 & 2.4 \\
\hline Total nitrogen & $\mathrm{g} / \mathrm{kg}$ & 0.2 & 0.2 \\
\hline $\begin{array}{l}\text { Ammonium nitrogen } \\
\left(\mathrm{NH}_{3}\right)\end{array}$ & $\mathrm{mg} / \mathrm{kg}$ & 19.9 & 15.9 \\
\hline Nitrate nitrogen $\left(\mathrm{NO}_{3}^{-}\right)$ & $\mathrm{mg} / \mathrm{kg}$ & 6.2 & 84.5 \\
\hline Nitrite nitrogen $\left(\mathrm{NO}_{2}^{-}\right)$ & $\mathrm{mg} / \mathrm{kg}$ & $<0.05$ & $<0.05$ \\
\hline $\begin{array}{l}\text { Effective phosphate } \\
\left(\mathrm{PO}_{4}^{3-}\right)\end{array}$ & $\mathrm{mg} / \mathrm{kg}$ & 12 & 40 \\
\hline Exchangeable $\mathrm{K}_{+}$ & $\mathrm{cmol}(+) / \mathrm{kg}$ & 0.34 & 0.36 \\
\hline Exchangeable $\mathrm{Ca}^{2+}$ & $\mathrm{cmol}(+) / \mathrm{kg}$ & 6.19 & 4.32 \\
\hline Exchangeable $\mathrm{Mg}^{2+}$ & $\mathrm{cmol}(+) / \mathrm{kg}$ & 0.44 & 0.94 \\
\hline Exchangeable $\mathrm{Na}^{+}$ & $\mathrm{cmol}(+) / \mathrm{kg}$ & 0.42 & 0.10 \\
\hline Exchangeable $\mathrm{Mn}^{2+}$ & $\mathrm{mg} / \mathrm{kg}$ & 1.52 & 3.07 \\
\hline Available iron (Fe) & $\mathrm{mg} / \mathrm{kg}$ & 142 & 10.4 \\
\hline $\mathrm{Cl}^{-}$ & $\mathrm{mg} / \mathrm{kg}$ & 15.7 & 12.4 \\
\hline Sulfate $\left(\mathrm{SO}_{4}^{2-}\right)$ & $\mathrm{mg} / \mathrm{kg}$ & 379 & 2 \\
\hline $\mathrm{Cd}^{a}$ & $\mathrm{mg} / \mathrm{l}$ & $<0.001$ & $<0.001$ \\
\hline $\operatorname{Cr}(\mathrm{VI})^{a}$ & $\mathrm{mg} / \mathrm{l}$ & $<0.005$ & $<0.005$ \\
\hline Total mercury $(\mathrm{Hg})^{a}$ & mg/l & $<0.0005$ & $<0.0005$ \\
\hline Alkyl mercury (Hg) ${ }^{a}$ & $\mathrm{mg} / \mathrm{l}$ & $<0.0005$ & $<0.0005$ \\
\hline $\mathrm{Pb}^{a}$ & $\mathrm{mg} / \mathrm{l}$ & $<0.004$ & $<0.004$ \\
\hline $\mathrm{As}^{a}$ & mg/l & $<0.001$ & 0.001 \\
\hline $\mathrm{B}^{a}$ & $\mathrm{mg} / \mathrm{l}$ & $<0.1$ & $<0.1$ \\
\hline $\mathrm{Cd}^{b}$ & $\mathrm{mg} / \mathrm{kg}$ & $<15$ & $<15$ \\
\hline $\operatorname{Cr}(\mathrm{VI})^{b}$ & $\mathrm{mg} / \mathrm{kg}$ & $<25$ & $<25$ \\
\hline $\mathrm{Hg}^{b}$ & $\mathrm{mg} / \mathrm{kg}$ & $<1.5$ & $<1.5$ \\
\hline $\mathrm{Pb}^{b}$ & $\mathrm{mg} / \mathrm{kg}$ & $<15$ & $<15$ \\
\hline$A s^{b}$ & $\mathrm{mg} / \mathrm{kg}$ & $<15$ & $<15$ \\
\hline $\mathrm{B}^{b}$ & $\mathrm{mg} / \mathrm{kg}$ & $<400$ & $<400$ \\
\hline $\mathrm{Cu}^{b}$ & $\mathrm{mg} / \mathrm{kg}$ & $<10$ & $<10$ \\
\hline $\mathrm{Zn}{ }^{b}$ & $\mathrm{mg} / \mathrm{kg}$ & 100 & 49 \\
\hline $\mathrm{Ni}{ }^{b}$ & $\mathrm{mg} / \mathrm{kg}$ & $<30$ & $<30$ \\
\hline
\end{tabular}

aElution amount of chemicals by water

${ }^{\text {b} T o t a l ~ a m o u n t ~ o f ~ c h e m i c a l s ~ c o n t a i n e d ~ i n ~ t h e ~ s o i l ~ s a m p l e ~}$

Using Kraken [33], 114,838 (14.0\%) and 112,459 (11.7\%) shotgun reads from Hiyoriyama and Amamiya were taxonomically classified, respectively. Almost all reads were assigned to Bacteria (99.01 and 98.99\%), whereas few reads were assigned to Archaea (0.81 and $0.63 \%$ ) and Viruses $(0.18$ and $0.38 \%)$. The microbial composition of abundant genera is shown in Additional file 5 . The most abundant genus in both samples was Burkholderia (4.85 and $7.20 \%$ ), followed by Bradyrhizobium (4.66 
Table 3 General features of the metagenome sequences

\begin{tabular}{lll}
\hline & Hiyoriyama & Amamiya \\
\hline Raw sequence reads & $1,091,366$ & $1,177,491$ \\
After quality control & $822,865(75.40 \%)$ & $961,221(81.60 \%)$ \\
CDSs & $1,170,916$ & $1,323,575$ \\
165 rRNAs & 628 & 633 \\
Taxonomically classified reads & $114,838(13.96 \%)$ & $112,459(11.70 \%)$ \\
- Bacteria & $113,696(99.01 \%)$ & $111,326(98.99 \%)$ \\
- Archaea & $933(0.81 \%)$ & $707(0.63 \%)$ \\
- Viruses & $209(0.18 \%)$ & $426(0.38 \%)$ \\
\hline
\end{tabular}

and $6.30 \%$ ), Rhodopseudomonas (3.27 and 3.46\%), and Pseudomonas (2.98 and $3.13 \%$ ). The similar composition of the major taxonomic groups reflects the similar overall chemical characteristics between the two soil samples. In addition, we estimated the typical habitats of the contained microbes by querying the extracted $16 \mathrm{~S}$ rRNA genes against MetaMetaDB [37], a database that links 16S rRNA gene sequences to environments based on comprehensive analysis of published metagenomic and ampliconsequencing datasets. The estimated habitats quantified as MHI values [37] showed that the top habitat was soil in both communities; however, the marine habitat was estimated to be modestly more abundant in Hiyoriyama, whereas the soil habitat was more abundant in Amamiya, as expected (Fig. 5).

Figure 6 displays the genera whose relative abundance substantially differed between the two samples, including only those whose abundance in one sample was more than three times greater than that in the other. Notably, Arthrobacter was the only genus that was both abundant in and differed substantialy between the two samples. Considering the fact that Arthrobacter was the genus cultivated in both the R2A and ZoBell media, we propose that this genus likely shows a greater potential for adaptation to tsunami-affected soils. The other genera that were more abundant in Hiyoriyama included Erysipelothrix, where all reads were assigned to a single species, Erysipelothrix rhusiopathiae [65], which is known to cause erysipelas, a bacterial skin infection, in animals [66]. Although previous culture-based studies reported several pathogen species (Mycobacterium elephantis, Massilia timonae, Vibrio ichthyoenteri, $V$. natriegens, and $V$. fluvialis) in sludge derived from tsunami-affected soil in Tohoku [13, 67], these species were not detected in the present dataset. It may also be notable that the genera detected only in Hiyoriyama included typical marine-living groups such as Croceibacter [68], Marinitoga [69], and Pyrococcus [70-72], implying that the tsunami facilitated microbial immigration.

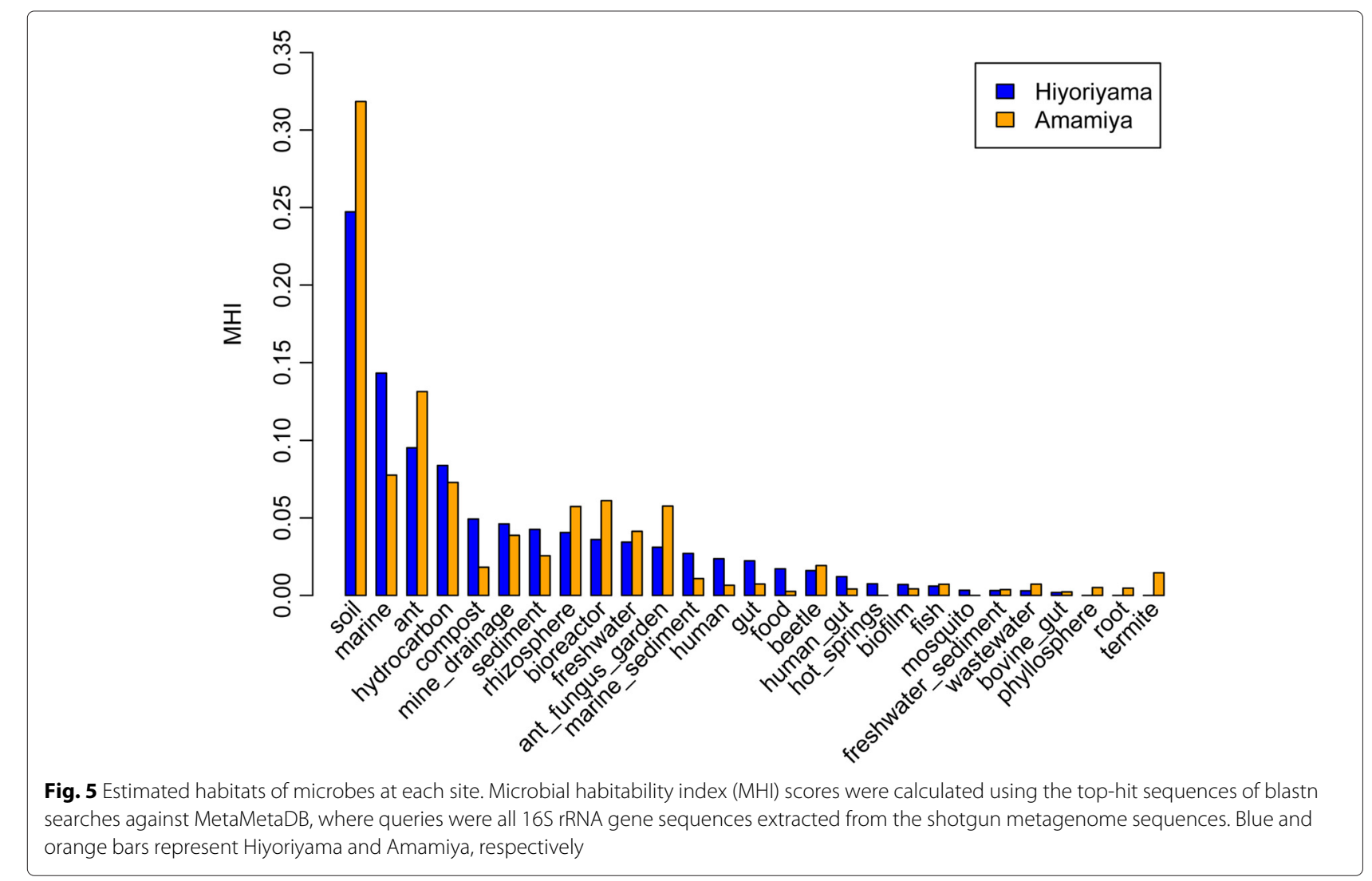




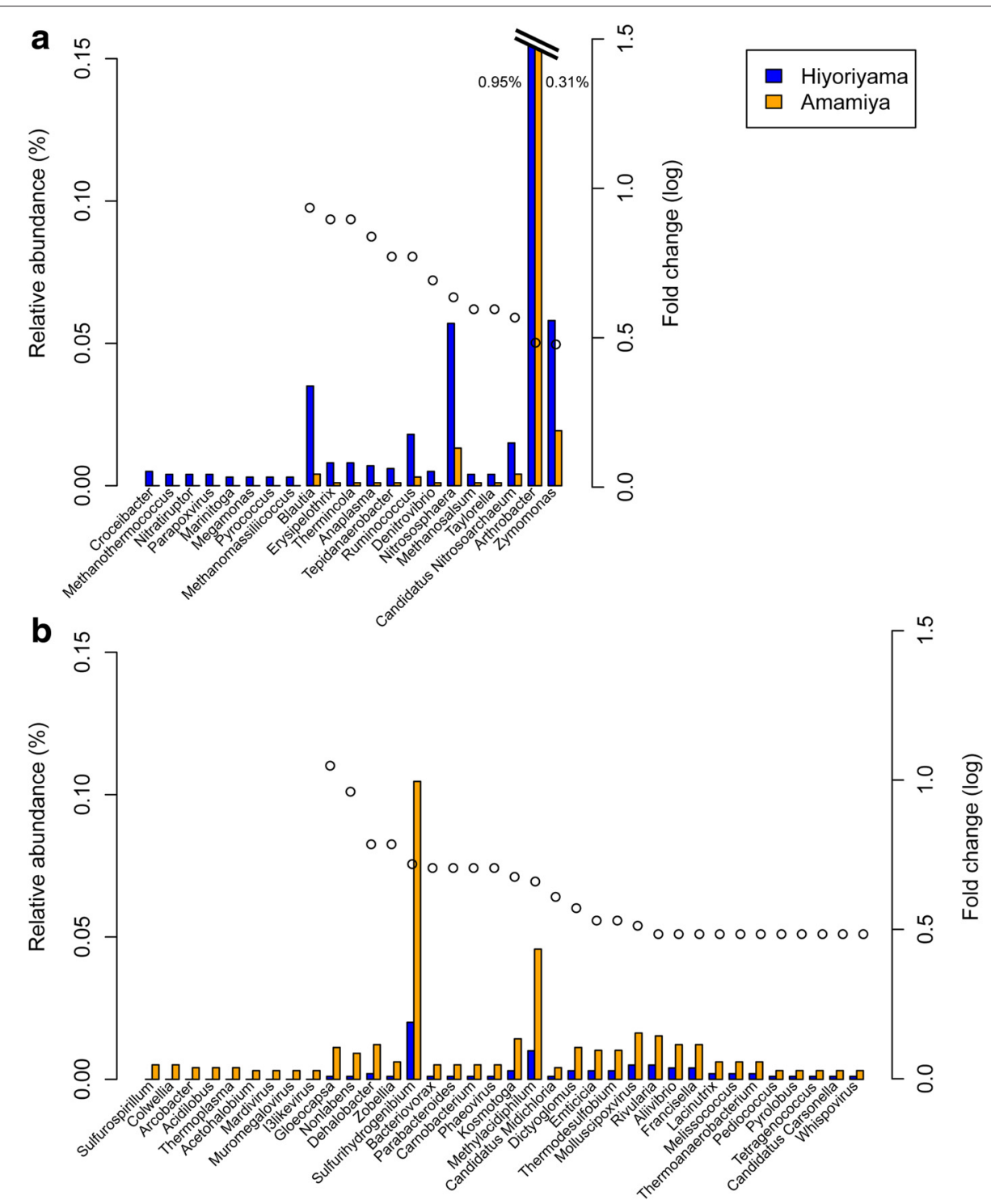

Fig. 6 Microbial genera with a substantial difference in abundance between the two sites. Genera whose relative abundance values differed by more than three times between the two sites and represented more than $0.003 \%$ of the total abundance in either of the two sites are displayed for genera overrepresented in $\mathbf{a}$ Hiyoriyama and $\mathbf{b}$ Amamiya. Blue and orange bars represent the relative abundance in Hiyoriyama and Amamiya, respectively. Dots represent the ratios of larger abundance values divided by smaller values, if the smaller value was not zero

We annotated the CDSs and investigated the relative abundance of nitrogen cycle-related genes, because the taxonomic analysis identified genera known to metabolize inorganic nitrogens, such as Bradyrhizobium, Azospirillum, Frankia, Mesorhizobium, Rhizobium, and Sinorhizobium (Additional file 5), and the chemical analysis revealed differences in the amount of nitrogen compounds (Table 2). The abundance of functional genes showed that genes related to denitrification and nitrogen fixation were more abundant in Hiyoriyama and genes related to nitrite reduction were more abundant in Amamiya (Fig. 7). In addition to the oxidization of iron-sulfur compounds, this dominance of denitrificationrelated genes at Hiyoriyama may be another cause of the relatively small amount of nitrate observed in Hiyoriyama (Table 2), which might affect terrestrial vegetation indirectly.

We also investigated the abundance of siderophoresynthesis genes in the shotgun metagenome data, but only three and four reads of genes that are involved in this process (bactNOG07545, bactNOG14638, bactNOG30540) were detected in Hiyoriyama and Amamiya, respectively, which is not a sufficient sample size for statistical analysis. Differences in sulfur metabolism genes were not as 

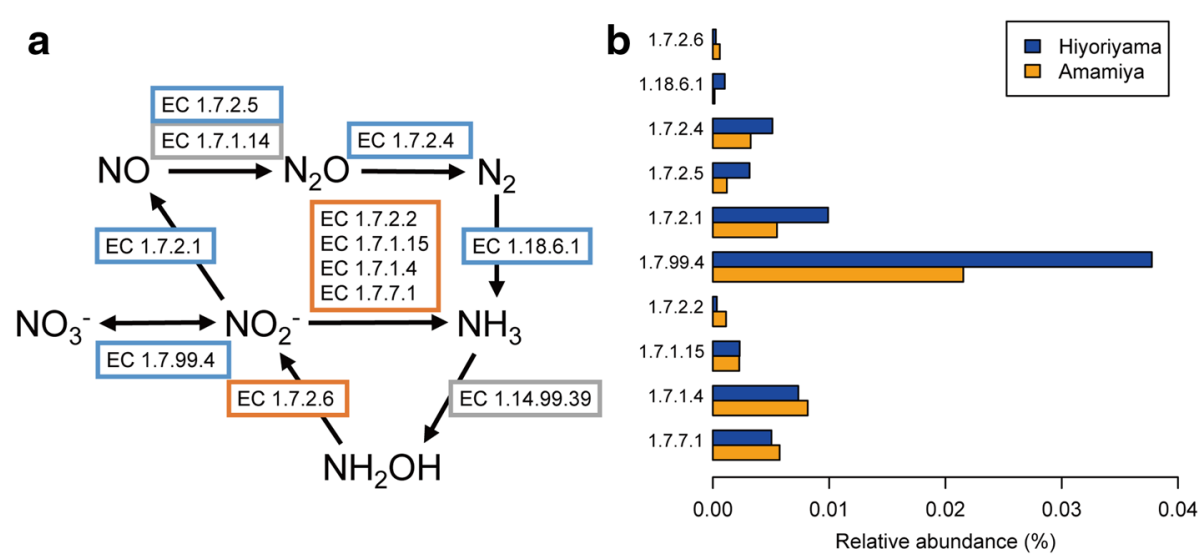

Fig. 7 Relative abundance of genes related to nitrogen metabolism. a A pathway map of nitrogen metabolism genes with Enzyme Commission numbers. Blue and orange rectangles represent genes that were found to be more abundant in Hiyoriyama and Amamiya, respectively. Gray rectangles represent genes not found in either sample. $\mathbf{b} \mathrm{A}$ bar plot of the relative abundance for each gene represented by an Enzyme Commission number

large as those of nitrogen metabolism genes. A substantial difference was observed in the numbers of cation transporter genes, where 127 and 59 monovalent cation $/ \mathrm{H}^{+}$ antiporter subunits, and 96 and $16 \mathrm{Na}^{+} / \mathrm{Ca}^{2+}$ antiporter family proteins (bactNOG00892) were detected in Hiyoriyama and Amamiya, respectively. These genes may have facilitated salt tolerance in the tsunami-affected soil, because cation transporters are known to function in bacterial salt tolerance $[73,74]$.

\section{Conclusion}

In this study, we isolated four Arthrobacter strains from a soil sample affected by the Tohoku tsunami and determined their whole-genome sequences. Independent losses of siderophore-synthesis genes were suggested in these genomes, which was consistent with the rich iron content detected in the tsunami-affected soil sample and the weak cultivability of the isolated strains in ironlimited media, although further experimental analysis will be needed to conclude it. The chemical and metagenomic analyses indicated that the tsunami-affected sample was largely similar to the unaffected sample, although some notable differences were observed regarding nitrogen metabolism and taxonomic composition. It should be noted that we cannot conclusively determine whether the isolated Arthrobacter strains were brought into the sampled area from sea and then adapted to soil, or were originally in the soil and survived under the tsunamiaffected conditions. In either case, it also remains undetermined whether the siderophore-synthesis genes were mutated after the tsunami or the strains that originally lost these genes were simply favored and selected in the tsunami-affected soil.

The Pacific coast of Tohoku, Japan has been flooded by tsunamis many times in history (more than 11 tsunamis were triggered in the last 200 years, according to [75]). Because a tsunami should affect the soil and its microbial communities in diverse manners, we envision that further comprehensive analyses on microbial ecology and evolution after a tsunami will be necessary to develop a deeper understanding of the recovery processes of terrestrial microbial ecosystems.

\section{Additional files}

Additional file 1: Arthrobacter dataset for comparative genome analysis. (PDF $66 \mathrm{~kb}$ )

Additional file 2: Relative abundance of functional gene categories in the Arthrobacter genomes. The relative abundance of CDSs assigned to each eggNOG functional category is plotted for each Arthrobacter genome. (PDF $166 \mathrm{~kb}$ )

Additional file 3: Phylogenetic tree of Arthrobacter genus. The phylogenetic tree was reconstructed using the maximum-likelihood method based on 165 rRNA sequences with Streptomyces coelicoflavus NBRC $15399^{\top}$ as an outgroup. Numbers adjacent to branch points are bootstrap percentages (1000 replicates). Symbols represent the available circular genomes (circle), available draft genomes (triangle), those isolated in this study (red), and those isolated in previous studies (blue). (TIF $920 \mathrm{~kb}$ )

Additional file 4: Growth curves of the Arthrobacter strains at different iron concentrations. Growth was measured as optical density values at $660 \mathrm{~nm}$ in modified MM9 medium containing different concentrations of iron (III): $0.0,0.1,1$, and $10 \mu \mathrm{M}$. Growth curves of Arthrobacter sp. Hiyo1 (A), Hiyo8 (B), Hiyo4 (C), Hiyo6 (D), and A. phenanthrenivorans Sphe3 (E) were measured. (TIF $380 \mathrm{~kb}$ )

Additional file 5: Abundant microbial genera determined in metagenome shotgun sequencing. The 30 most abundant microbial genera at Hiyoriyama and their relative abundance at both sites are displayed. Blue and orange bars represent Hiyoriyama and Amamiya, respectively. (TIF $567 \mathrm{~kb}$ )

Competing interests

The authors declare that they have no competing interests.

Authors' contributions

SH conceived and designed the study, performed the bioinformatics analyses and growth experiments, and wrote the manuscript. AM conceived and 
designed the study, performed the culture experiments, DNA extraction, and bioinformatics analyses, and contributed to the writing of the manuscript. MI and $\mathrm{KI}$ conceived, designed, and participated in the experiments. $\mathrm{KO}$ and $\mathrm{MH}$ performed the genomic and metagenomic sequencing. SY and KK participated in the design of the study and supervised the project. WI conceived and designed the study, wrote the manuscript, and supervised the project. All authors read and approved the final manuscript.

\section{Acknowledgements}

We would like to thank Shotaro Hirase, Shotaro Suzuki, Hiromi Kato, Seok-Won Kim, and officers and crew of R/V Tansei-Maru for sample collection and sequence analysis, and Haruka Ozaki, Yohei Kumagai, and Motomu Matsui for providing insightful comments. PacBio sequencing was provided by the PacBio free sequence campaign by Tomy Digital Biology Co. Ltd (Tokyo Japan).

\section{Author details}

${ }^{1}$ Department of Computational Biology and Medical Sciences, Graduate School of Frontier Sciences, the University of Tokyo, 277-8568, Chiba, Japan. ${ }^{2}$ Department of Biological Sciences, Graduate School of Science, the University of Tokyo, 113-0032, Tokyo, Japan. ${ }^{3}$ Atmosphere and Ocean Research Institute, the University of Tokyo, 277-8564, Chiba, Japan. ${ }^{4}$ Center for Omics and Bioinformatics, Graduate School of Frontier Sciences, The University of Tokyo, 277-8561, Chiba, Japan.

\section{Received: 7 October 2015 Accepted: 6 January 2016} Published online: 14 January 2016

\section{References}

1. Simons M, Minson SE, Sladen A, Ortega F, Jiang J, Owen SE, et al. The 2011 magnitude 9.0 Tohoku-Oki earthquake: Mosaicking the megathrust from seconds to centuries. Science. 2011;332(6036):1421-5.

2. McLeod MK, Slavich P, Irhas Y, Moore N, Rachman A, Ali N, et al. Soil salinity in Aceh after the December 2004 Indian Ocean tsunami. Agric Water Manag. 2010;97(5):605-13.

3. Rengalakshmi R, Senthilkumar R, Selvarasu T, Thamizoli P. Reclamation and status of tsunami damaged soil in Nagappattinam District, Tamil Nadu. Curr Sci. 2007;92(9):1221-3.

4. Ranjan RK, Ramanathan AL, Singh G. Evaluation of geochemical impact of tsunami on Pichavaram mangrove ecosystem, southeast coast of India. Environ Geol. 2008:55(3):687-97.

5. Szczuciński W, Niedzielski P, Rachlewicz G, Sobczyński T, Zioła A, Kowalski A, et al. Contamination of tsunami sediments in a coastal zone inundated by the 26 December 2004 tsunami in Thailand. Environ Geol. 2005:49(2):321-31.

6. Srinivasalu S, Thangadurai N, Jonathan MP, Armstrong-Altrin J, Ayyamperumal T, Ram-Mohan V. Evaluation of trace-metal enrichments from the 26 December 2004 tsunami sediments along the Southeast coast of India. Environ Geol. 2008;53(8):1711-21.

7. Prasath P, Khan TH. Impact of Tsunami on the heavy metal accumulation in water, Sediments and fish at Poompuhar coast, Southeast Coast of India. J Chem. 2008;5(1):16-22.

8. Chandrasekharan H, Sarangi A, Nagarajan M, Singh V, Rao D, Stalin P, et al. Variability of soil-water quality due to Tsunami-2004 in the coastal belt of Nagapattinam district, Tamilnadu. J Environ Manag. 2008;89(1):63-72.

9. Szczucinski W, Chaimanee N, Niedzielski P, Rachlewicz G, Saisuttichai D, Tepsuwan T, et al. Environmental and geological impacts of the 26 December 2004 tsunami in coastal zone of Thailand-overview of short and long-term effects. Pol J Environ Stud. 2006;15(5):793-810.

10. Curran PJ, Dash J, Llewellyn GM. Indian Ocean tsunami: The use of MERIS (MTCI) data to infer salt stress in coastal vegetation. Int J Remote Sensing. 2007;28(3-4):729-35.

11. Hayasaka D, Shimada N, Konno H, Sudayama H, Kawanishi M, Uchida T, et al. Floristic variation of beach vegetation caused by the 2011 Tohoku-oki tsunami in northern Tohoku, Japan. Ecol Eng. 2012;44:227-32.

12. Somboonna N, Wilantho A, Jankaew K, Assawamakin A, Sangsrakru D, Tangphatsornruang $\mathrm{S}$, et al. Microbial ecology of Thailand tsunami and non-tsunami affected terrestrials. PLoS ONE. 2014;9(4):e94236.

13. Wada K, Fukuda K, Yoshikawa T, Hirose T, Ikeno T, Umata T, et al. Bacterial hazards of sludge brought ashore by the tsunami after the great East Japan earthquake of 2011. J Occup Health. 2012;54(4):255-62.
14. Crosa JH. Genetics and molecular biology of siderophore-mediated iron transport in bacteria. Microbiol Rev. 1989;53(4):517-30.

15. Neilands JB. Siderophores: structure and function of microbial iron transport compounds. J Biol Chem. 1995;270(45):26723-6.

16. Hider RC, Kong X. Chemistry and biology of siderophores. Nat Product Rep. 2010;27(5):637-57.

17. Lane DJ. 16S/23S rRNA sequencing In: Stackebrandt E, Goodfellow M, editors. Nucleic Acid Techniques in Bacterial Systematics. Chichester, United Kingdom: John Wiley and Sons; 1991. p. 125-75.

18. Margulies M, Egholm M, Altman WE, Attiya S, Bader JS, Bemben LA, et al. Genome sequencing in microfabricated high-density picolitre reactors. Nature. 2005;437(7057):376-80.

19. Hyatt D, Chen GL, LoCascio P, Land M, Larimer F, Hauser L. Prodigal: prokaryotic gene recognition and translation initiation site identification. BMC Bioinformatics. 2010;11(1):119.

20. Camacho C, Coulouris G, Avagyan V, Ma N, Papadopoulos J, Bealer K, et al. BLAST+: architecture and applications. BMC bioinformatics. 2009;10(1):421.

21. UniProt Consortium. Update on activities at the Universal Protein Resource (UniProt) in 2013. Nucleic Acids Res. 2013;41(D1):43-7.

22. Powell S, Forslund K, SzklarczykD, Trachana K, Roth A, Huerta-Cepas J, et al. eggNOG v4.0: nested orthology inference across 3686 organisms. Nucleic Acids Res. 2014;42(D1):231-9. doi:10.1093/nar/gkt1253.

23. Lowe TM, Eddy SR. tRNAscan-SE: a program for improved detection of transfer RNA genes in genomic sequence. Nucleic Acids Res. 1997;25(5): 0955-64.

24. Lagesen $K$, Hallin P, Rødland EA, Stærfeldt HH, Rognes T, Ussery DW. RNAmmer: consistent and rapid annotation of ribosomal RNA genes. Nucleic Acids Res. 2007;35(9):3100-108.

25. Benson DA, Cavanaugh M, Clark K, Karsch-Mizrachi I, Lipman DJ, Ostell J, et al. GenBank. Nucleic Acids Res. 2013;41(D1):36-42.

26. Cole JR, Wang Q, Fish JA, Chai B, McGarrell DM, Sun Y, et al. Ribosomal Database Project: data and tools for high throughput rRNA analysis. Nucleic Acids Res. 2014;42(D1):633-42. doi:10.1093/nar/gkt1244.

27. Yao Y, Tang H, Su F, Xu P. Comparative genome analysis reveals the molecular basis of nicotine degradation and survival capacities of arthrobacter. Sci Rep. 2015;5:8642.

28. Edgar RC. MUSCLE: multiple sequence alignment with high accuracy and high throughput. Nucleic Acids Res. 2004;32(5):1792-7.

29. Tamura K, Stecher G, Peterson D, Filipski A, Kumar S. MEGA6: Molecular Evolutionary Genetics Analysis Version 6.0. Mol Biol Evol. 2013;30(12): 2725-729.

30. Segata N, Börnigen D, Morgan XC, Huttenhower C. Phylophlan is a new method for improved phylogenetic and taxonomic placement of microbes. Nat Commun. 2013;4:2304.

31. Payne SM. Detection, isolation, and characterization of siderophores. Methods Enzymol. 1994;235:329-44.

32. Niu B, Fu L, Sun S, Li W. Artificial and natural duplicates in pyrosequencing reads of metagenomic data. BMC Bioinformatics. 2010;11(1):187.

33. Wood DE, Salzberg SL. Kraken: ultrafast metagenomic sequence classification using exact alignments. Genome Biol. 2014;15(3):46.

34. Tatusova T, Ciufo S, Fedorov B, O'Neill K, Tolstoy I. RefSeq microbial genomes database: new representation and annotation strategy. Nucleic Acids Res. 2014;42(D1):553-9. doi:10.1093/nar/gkt1274.

35. Hyatt D, LoCascio PF, Hauser $\sqcup$, Uberbacher EC. Gene and translation initiation site prediction in metagenomic sequences. Bioinformatics. 2012;28(17):2223-30.

36. Kopylova E, Noé L, Touzet H. SortMeRNA: fast and accurate filtering of ribosomal RNAs in metatranscriptomic data. Bioinformatics. 2012;28(24): 3211-7.

37. Yang CC, Iwasaki W. MetaMetaDB: A database and analytic system for investigating microbial habitability. PloS ONE. 2014;9(1):e87126.

38. Jones D, Keddie RM. The genus Arthrobacter In: Dworkin MM, Falkow S, Rosenberg E, Schleifer KH, Stackebrandt E, editors. The Prokaryotes. New York: Springer; 2006. p. 945-60.

39. Cacciari I, Lippi D. Arthrobacters: successful arid soil bacteria: a review. Arid Land Res Manag. 1987;1(1):1-30.

40. Crocker FH, Fredrickson JK, White DC, Ringelberg DB, Balkwill DL. Phylogenetic and physiological diversity of Arthrobacter strains isolated from unconsolidated subsurface sediments. Microbiology. 2000;146(6): 1295-310. 
41. Bowman JP, McCammon SA, Brown MV, Nichols DS, McMeekin TA. Diversity and association of psychrophilic bacteria in Antarctic sea ice. Appl Environ Microbiol. 1997;63(8):3068-78.

42. Fredrickson JK, Zachara JM, Balkwill DL, Kennedy D, Shu-mei WL, Kostandarithes HM, et al. Geomicrobiology of high-level nuclear waste-contaminated vadose sediments at the Hanford Site, Washington State. Appl Environ Microbiol. 2004;70(7):4230-41.

43. Trajanovska S, Britz ML, Bhave M. Detection of heavy metal ion resistance genes in Gram-positive and Gram-negative bacteria isolated from a lead-contaminated site. Biodegradation. 1997;8(2):113-24.

44. Boylen CW. Survival of Arthrobacter crystallopoietes during prolonged periods of extreme desiccation. J Bacteriol. 1973;113(1):33-7.

45. Ensign JC. Long-term starvation survival of rod and spherical cells of Arthrobacter crystallopoietes. J Bacteriol. 1970;103(3):569-77.

46. Margesin R, Schinner F. Heavy metal resistant Arthrobacter sp.-A tool for studying conjugational plasmid transfer between Gram-negative and Gram-positive bacteria. J Basic Microbiol. 1997;37(3):217-27.

47. Bafana A, Krishnamurthi K, Patil M, Chakrabarti T. Heavy metal resistance in Arthrobacter ramosus strain G2 isolated from mercuric salt-contaminated soil. J Hazardous Mater. 2010;177(1):481-6.

48. Suzuki Y, Banfield JF. Resistance to, and accumulation of, uranium by bacteria from a uranium-contaminated site. Geomicrobiol J. 2004;21(2): 113-21.

49. Guerinot ML. Microbial iron transport. Ann Rev Microbiol. 1994;48(1): $743-72$.

50. Sugiura Y, Nomoto K. Phytosiderophores structures and properties of mugineic acids and their metal complexes In: Clarke MJ, Ibers JA, Mingos DMP, Palmer GA, Sadler PJ, Williams RJP, editors. Siderophores from Microorganisms and Plants. Berlin, Heidelberg: Springer; 1984. p. 107-35.

51. Jurkevitch E, Hadar Y, Chen Y. Differential siderophore utilization and iron uptake by soil and rhizosphere bacteria. Appl Environ Microbiol. 1992;58(1):119-24.

52. Barona-Gómez F, Wong U, Giannakopulos AE, Derrick PJ, Challis GL. Identification of a cluster of genes that directs Desferrioxamine Biosynthesis in Streptomyces coelicolor M145. J Am Chem Soc 2004;126(50):16282-3.

53. Günter K, Toupet C, Schupp T. Characterization of an iron-regulated promoter involved in desferrioxamine B synthesis in Streptomyces pilosus: repressor-binding site and homology to the diphtheria toxin gene promoter. J Bacteriol. 1993;175(11):3295-302.

54. Schwyn B, Neilands JB. Universal chemical assay for the detection and determination of siderophores. Anal Biochem. 1987;160(1):47-56.

55. Shenker $M$, Chen $Y$. Increasing iron availability to crops: fertilizers, organo-fertilizers, and biological approaches. Soil Sci Plant Nutrition. 2005;51(1):1-17.

56. Radzki W, Mañero FJG, Algar E, García JAL, García-Villaraco A, Solano BR. Bacterial siderophores efficiently provide iron to iron-starved tomato plants in hydroponics culture. Antonie van Leeuwenhoek. 2013;104(3): 321-30.

57. Duhan JS, Dudeja SS, Khurana AL. Siderophore production in relation to $\mathrm{N}_{2}$ fixation and iron uptake in pigeon pea-Rhizobium symbiosis. Folia Microbiologica. 1998;43(4):421-6. doi:10.1007/BF02818585.

58. Jflrgensen BB. The sulfur cycle of a coastal marine sediment (Limfjorden, Denmark). Limnol Oceanograph. 1977;22:814-32.

59. Schippers A, Jørgensen BB. Biogeochemistry of pyrite and iron sulfide oxidation in marine sediments. Geochimica et Cosmochimica Acta. 2002;66(1):85-92.

60. Garcia-Gil LJ, Golterman HL. Kinetics of FeS-mediated denitrification in sediments from the Camargue (Rhone delta, southern France). FEMS Microbiol Ecol. 1993;13(2):85-91.

61. Straub KL, Benz M, Schink B, Widdel F. Anaerobic, nitrate-dependent microbial oxidation of ferrous iron. Appl Environ Microbiol. 1996;62(4): $1458-1460$.

62. Hauck S, Benz M, Brune A, Schink B. Ferrous iron oxidation by denitrifying bacteria in profundal sediments of a deep lake (Lake Constance). FEMS Microbiol Ecol. 2001;37(2):127-34.

63. Haaijer SCM, Lamers LPM, Smolders AJP, Jetten MSM, Op den Camp HJ. Iron sulfide and pyrite as potential electron donors for microbial nitrate reduction in freshwater wetlands. Geomicrobiol J. 2007;24(5):391-401.
64. Szczuciński W, Niedzielski P, Kozak L, Frankowski M, Zioła A, Lorenc S. Effects of rainy season on mobilization of contaminants from tsunami deposits left in a coastal zone of Thailand by the 26 December 2004 tsunami. Environ Geol. 2007;53(2):253-64.

65. Ogawa Y, Ooka T, Shi F, Ogura Y, Nakayama K, Hayashi T, et al. The genome of Erysipelothrix rhusiopathiae, the causative agent of swine erysipelas, reveals new insights into the evolution of Firmicutes and the organism's intracellular adaptations. J Bacteriol. 2011;193(12):2959-71. doi:10.1128/JB.01500-10.

66. Veraldi S, Girgenti V, Dassoni F, Gianotti R. Erysipeloid: a review. Clinical Exp Dermatol. 2009;34(8):859-62.

67. Makita K, Inoshita K, Kayano T, Uenoyama K, Hagiwara K, Asakawa M, et al. Temporal changes in environmental health risks and socio-psychological status in areas affected by the 2011 tsunami in Ishinomaki, Japan. Environ Pollut. 2013;3(1):1.

68. Cho JC, Giovannoni SJ. Croceibacter atlanticus gen. nov., sp. nov., a novel marine bacterium in the family Flavobacteriaceae. Syst Appl Microbiol. 2003;26(1):76-83.

69. Alain K, Marteinsson VT, Miroshnichenko ML, Bonch-Osmolovskaya EA, Prieur D, Birrien JL. Marinitoga piezophila sp. nov., a rod-shaped, thermopiezophilic bacterium isolated under high hydrostatic pressure from a deep-sea hydrothermal vent. Int J Syst Evol Microbiol. 2002;52(4):1331-9.

70. Fiala G, Stetter KO. Pyrococcus furiosus sp. nov. represents a novel genus of marine heterotrophic archaebacteria growing optimally at $100^{\circ} \mathrm{C}$. Arch Microbiol. 1986;145(1):56-61.

71. Erauso G, Reysenbach AL, Godfroy A, Meunier JR, Crump B, Partensky F, et al. Pyrococcus abyssi sp. nov., a new hyperthermophilic archaeon isolated from a deep-sea hydrothermal vent. Arch Microbiol. 1993;160(5): 338-49.

72. Zeng X, Birrien JL, Fouquet Y, Cherkashov G, Jebbar M, Querellou J, et al. Pyrococcus $\mathrm{CH}$, an obligate piezophilic hyperthermophile: extending the upper pressure-temperature limits for life. ISME J. 2009;3(7): 873-6.

73. Oren A, Heldal M, Norland S, Galinski EA. Intracellular ion and organic solute concentrations of the extremely halophilic bacterium Salinibacter ruber. Extremophiles. 2002;6(6):491-8.

74. Kosono S, Haga K, Tomizawa R, Kajiyama Y, Hatano K, Takeda S, et al. Characterization of a multigene-encoded sodium/hydrogen antiporter (Sha) from Pseudomonas aeruginosa: its involvement in pathogenesis. J Bacteriol. 2005;187(15):5242-248.

75. Sugawara D, Goto K, Imamura F, Matsumoto H, Minoura K. Assessing the magnitude of the 869 Jogan tsunami using sedimentary deposits: Prediction and consequence of the 2011 Tohoku-oki tsunami. Sedimentary Geol. 2012;282:14-26.

\section{Submit your next manuscript to BioMed Central and we will help you at every step:}

- We accept pre-submission inquiries

- Our selector tool helps you to find the most relevant journal

- We provide round the clock customer support

- Convenient online submission

- Thorough peer review

- Inclusion in PubMed and all major indexing services

- Maximum visibility for your research

Submit your manuscript at www.biomedcentral.com/submit 